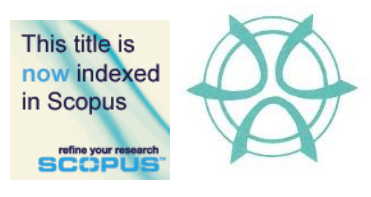

PLANNING MALAYSIA:

Journal of the Malaysian Institute of Planners

VOLUME 16 ISSUE 3 (2018) Page 248 - 260

\title{
DEVELOPING MALAYSIAN ROADSIDE TREE SPECIES SELECTION MODEL IN URBAN AREAS
}

\author{
Ramly Hasan $^{1}$, Noriah Othman ${ }^{2} \&$ Faridah Ismail $^{3}$ \\ ${ }^{1,2,3}$ Faculty of Architecture, Planning and Surveying \\ UNIVERSITI TEKNOLOGI MARA, MALAYSIA
}

\begin{abstract}
Urban trees are living organisms and vital elements of a city's infrastructure; thus, they should be considered at every stage of planning design and development. In Malaysia, rapid changes in the environment have indirectly influenced the roadside tree condition such as fallen trees. This is reflected with the statistic increment of public complaints by 39\% from 2014 until 2016 regarding the roadside tree problems, which are very worrying for the local authorities. This study aims to develop a Malaysian Roadside Tree Species Selection for guidance in selecting the right tree species for a sustainable city. The objectives of this study are (i) to determine additional attributes in roadside tree species selection, (ii) to examine the relationship between existing and additional attributes and (iii) to develop a Malaysian Roadside Tree Species Selection Model based on these attributes. This research applied the quantitative and qualitative approaches. The results produced a Malaysian Roadside Tree Species Selection Model.
\end{abstract}

Keywords: roadside tree, public complaint, tree species selection model 
PLANNING MALAYSIA

Journal of the Malaysia Institute of Planners (2018)

\section{INTRODUCTION}

Urban roadside trees have been introduced to the city areas since early civilization for functional and aesthetic purposes. Trees have been fostering many valuable functions in our lives from giving shade, providing a source of food and producing economic benefits. The right roadside trees species selection is important to create an exciting environment, provide shades, protection from vehicle light glare, sound barrier, and reduce dust pollution. As reported by Sreetheran, Adnan and Khairil Azuar (2011), the popular tree species planted in Malaysian urban areas are Peltophorum pterocarpum (yellow flame), Samanea saman (rain tree), Cinnamomum iners (wild cinnamon), Lagerstroemia speciosa (pride of India), Ficus benjamina (weeping fig), Mimusops elengi (tanjung), Millettia atropurpurea (purple millettia), Delonix regia (red flame) and Swietenia macrophylla (mahogany). The aim of this study is to develop a Malaysian Roadside Tree Species Selection for guidance in selecting the right trees species. The objectives of this study are (i) to determine additional attributes in roadside tree species selection, (ii) to examine the relationship between existing and additional attributes and (iii) to develop a Malaysian Roadside Tree Species Selection Model based on these attributes.

\section{UNDERSTANDING VALUES OF ROADSIDE TREE FOR HIGH QUALITY URBAN LIFESTYLE}

Benefits of roadside trees are continuously discussed in previous research in terms of environmental, social, economic, health, and aesthetic benefits (Hasan, Othman, \& Ismail, 2016; Vogt et al., 2017; Kondo, Han, Donovan, \& MacDonald, 2017; Salmond et al., 2016; Mullaney, Lucke, \& Trueman, 2015; Roy, Byrne, \& Pickering, 2012). All the benefits are contributed to creating an urban fabric and improving the quality of urban lifestyles. However, some of the current landscape practices lack the basic knowledge that underlies the science and art of incorporating trees into an urban area (Wiseman, 2017). Some planting design standards show that little is known about the basic needs of trees and the selection of the tree planting. In addition, space constraint in cities means that there are only limited opportunities for increasing tree density within the existing urban fabric and it is unclear whether the net effect of increased vegetation in street canyons is beneficial or detrimental to urban air quality at local scales (Salmond et al., 2013).

\section{PROBLEMS OF MALAYSIAN ROADSIDE TREE SPECIES SELECTION}

Rapid urban growth changes in the environment have indirectly influenced the roadside tree conditions (Krzyżaniak, Świerk, Walerzak, \& Urbański, 2015; Battipaglia et al., 2010; Sieghardt et al., 2005; Moore, 2009). According to the statistics of public complaints (Sistem Talian Aduan Rakyat, 2017 and IResponz 
Ramly Hasan, Noriah Othman \& Faridah Ismail

Developing Malaysian Roadside Tree Species Selection Model in Urban Areas

system, 2017), four selected local authorities namely the Kuala Lumpur City Hall, Petaling Jaya City Council, Subang Jaya Municipal Council and Selayang Municipal Council have shown nine issues of tree problems such as fallen trees (1,662 cases), brittle branches ( 2,142 cases), obscure visibility ( 1,493 cases), dead leaves and debris on the road (1,610 cases), heavy branches obstruct traffic (1,471 cases), old and dead trees (1,300 cases), clogged drainage system due to debris (1,596 cases), close proximity of trees to houses (181 cases) and leaning tree trunk (1,191 cases). As supported by Yan and Jung (2018), certain trees planted in urban areas are species with vigorous growth habit, fragile stems, weak bifurcation and are susceptible to diseases. These problems occur when several factors such as site, economic and social factors are not considered during the tree species selection practice (Miller, Hauer, \& Werner, 2015). The increasing number of public complaints caused the local authority to spend more than a hundred thousand Ringgit Malaysia to pay for the compensations (Yaman, Jamil, \& Yaakob, 2011).

The findings of the survey conducted by the author in 2016 concluded that there the level of knowledge in tree species selection practice in Malaysia is considered as low. This is because the landscape practices are more concerned about landscape design and aesthetical values compared to the function of tree species. As reported by Nor Azah (2015), the selection of tree species at local authority faces problems in terms of lack of expertise and experience to decide on the right tree species. Because of that, many of roadside trees have caused problems and the total number of public complaints related to the roadside tree have increased over the years.

THE ATTRIBUTES INFLUENCING THE TREE SPECIES SELECTION Miller et al. (2015) established a model to explain the urban roadside tree species selection. The model classified the factors contributing to the appropriate tree species selection for urban areas into three distinct categories which are site factors, social factors and economic factors. The site factors consist of cultural and environmental constraints. Miller et al. (2015) listed the physical limitation aspects on the site such as activities created by humans, utilities, structures, surface cover and pollution, which are referred to as cultural constraints, while insects, disease, soils, edaphic, physiographic, climate and microclimate are referred to as environmental constraints. As explained by Pauleit et al. (2002), edaphic constraint refers to soil conditions such as texture, drainage and chemical properties. The climatic constraints (Schroeder, Flannigan \& Coles, 2006) are clearly identified as part of the model. The social factors focus on aesthetic values, functional utility and negative externalities. Finally, there are economic factors which include establishment costs, maintenance cost and removal costs.

The conflict between bio-physical issues (ecosystem services and site factors) and socio-economic issues (institutional framework and culture, cost and 
residents expectation) of the species selection has been reported by Australian tree managers and council officers at City Councils in South-East Queensland, Australia. Roy (2014) added 'institutional factors' which include legislation, framework and culture to Miller et al. (2015) model to recognise the impact of these new factors on roadside tree species selection. The sets of factors have been clustered as socio-economic factors. Roy (2014) also added 'tree characteristics' including ecosystem services, disservices, performance and tolerance of proposed tree species, as well as the aspects of structure, diversity and performance of the existing roadside tree populations to the site factors to explicitly state and emphasise their importance among the selection factors. In addition, Roy (2014) revised the 'social factors' mentioned by Miller et al. (2015) model with 'sociocultural' factors to incorporate the effect of perception, attitudes and preference of tree managers, residents, politicians and stakeholders on species selection.

\section{RESEARCH METHODOLOGY}

This research applied the quantitative and qualitative approaches (Figure 1). During Phase 1, in-depth interview was conducted with 12 senior landscape architects in selected local authorities; Kuala Lumpur City Hall, Petaling Jaya City Council, Selayang Municipal Council and Selayang Municipal Council. The choice of local authorities in this research was based on the approval for data sharing from their landscape department. The selection of the respondents was based on expertise, experience and knowledge in roadside tree selection. The data were analysed in ATLAS.ti software. During Phase 2, a questionnaire survey was developed, tested and distributed among 500 registered landscape architects of the Institute of Landscape Architects Malaysia (ILAM). However, only 375 sets of the questionnaires were filled by the respondents. Responses to close-ended questions were analysed using the Statistical Package for Social Sciences (SPSS) version 21 software, while open-ended ones were analysed using the ATLAS.ti software.

Figure 1: Flow of research methodology

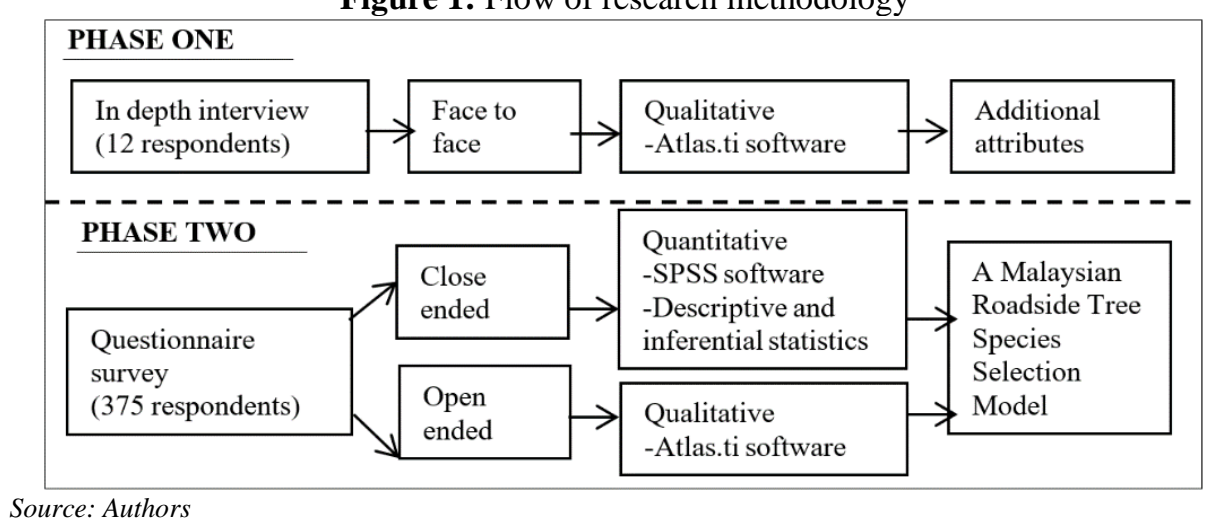


Ramly Hasan, Noriah Othman \& Faridah Ismail

Developing Malaysian Roadside Tree Species Selection Model in Urban Areas

\section{RESULTS AND DISCUSSION}

\section{Interview Results with Senior Landscape Architects to Define the Additional Attributes in Roadside Tree Species Selection Model}

The analysis of the interview results with 12 senior landscape architects in the local authorities is shown in Figure 2. Interviewees mentioned that six additional attributes that contribute in selecting roadside tree species are; framework and plan, trending, landscape policies, decision maker, limiting factors and themes. All the respondents stated trending, landscape policies and decision maker as the most important attributes that govern the selection of urban roadside tree species. Responses related to framework and plan $(\mathrm{N}=2)$ were also categorised according to the standard operation procedure (SOP), roadside landscape plan, list of roadside tree species and planting plan. Trending $(\mathrm{N}=12)$ was categorised according to the characteristics of the urban tree such as flowering trees, aesthetical values and tree forms. For the landscape policies $(\mathrm{N}=12)$, the elements highlighted by respondents were the National Landscape Policy (NLP), National Urbanisation Policy (NUP), Environmental Policy (EP) and Landscape Planning Guidelines (LPG). Respondents explained that decision makers $(\mathrm{N}=12)$ refers to people who have the authority to make decisions for selecting roadside tree species. Respondents stated that three groups in charge of selecting tree species are landscape architects, arborists and people in the top management level. Three of the respondents stated that important elements for limiting factors $(\mathrm{N}=3)$ are spaces and location of the planting trees. These elements will determine the conditions of tree growth. Attributes for themes $(\mathrm{N}=6)$ included types of tree species and suitable tree species for a variety of road types. Themes of tree species were determined based on the road hierarchy; main road, secondary road and highway. The identification of additional attributes showed the difference in views between Roy's (2014) and Miller et al. (2015) models. These different outlooks by the Malaysian local authorities suggest that revision to the Tree Species Selection Model proposed by Roy (2014) is necessary. The revised Tree Selection Model is to add the additional attributes in selecting roadside tree species. Via the improvement of this model, it can be used for local authorities as a guide for the selection of tree species, especially in Malaysia. This is because the conditions of Malaysia and others countries are different in terms of tree species, technology, climate conditions, weather and topography. 
PLANNING MALAYSIA

Journal of the Malaysia Institute of Planners (2018)

Figure 2: New Attributes for revised Tree Selection Model

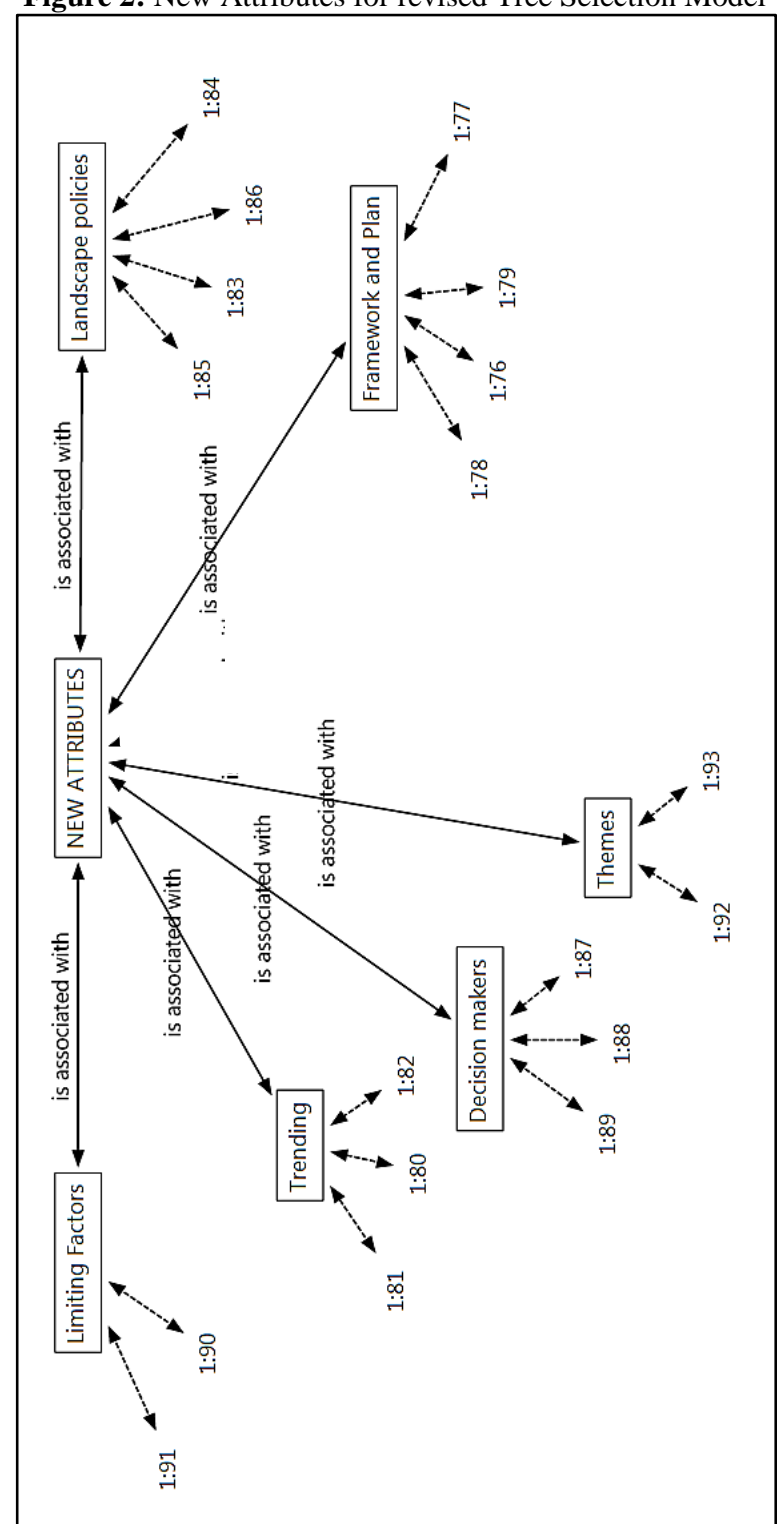

Note: Limiting Factors: 1:91=Space, 1:90=Location

Trending: 1.80=Flowering tree, 1:81=Aesthetical value, 1:82=Tree form

Decision makers: 1:89=Landscape architects, 1:88=Arborist, 1:87=Senior officer

Themes: 1:92=Type of tree species, 1:93=Suitable tree species

Landscape policies: 1:85=National Landscape Policy (NLP), 1:83=National

Urbanisation Policy (NUP), 1:86=Environmental Policy (EP), 1:84= Landscape

Planning Guidelines (LPG)

Framework and Plan: 1:78=Standard Operation Procedure (SOP), 1:76=Roadside

Landscape Plan, 1:79=List of roadside tree species, 1:77=Planting plan 
Ramly Hasan, Noriah Othman \& Faridah Ismail

Developing Malaysian Roadside Tree Species Selection Model in Urban Areas

\section{Ranking of Mean Results for Additional Attributes}

Table 1 shows the ranking of mean for additional attributes influencing roadside tree selection. The analysis shows the most influential attribute based on the ranking of mean is trending (mean $=4.70$, rank 1 ). The second influential roadside tree selection is landscape policies (mean $=4.50$, rank 2 ). The third influential selection of roadside trees is decision maker (mean $=4.41$, rank 3 ). Next is the limiting factor (mean $=4.08$, rank 4 ). This is followed by framework and plan (mean $=3.94$, rank 5) and lastly, themes (mean $=3.82$, rank 6). As mentioned in the literature review, trending is one important attribute in selecting trees. As supported by Key, Warner, McGraw and Fajvan (2001), 'trending' is the selection of tree species based on deciduous tree species and hardwood tree. The selection of tree species based on 'trending' is due to the continuity of the existing tree that has been planted before. The site condition such as climate factors and soil condition has been taken into account in selecting the appropriate tree species for the area. In the Malaysian context, the flowering tree (Tabebuia rosea, Peltophorum pterocarpum and Xanthostemon chrysanthus) has become 'trending' for roadside tree planting (Ahmad Nazarudin, 2016; Sreetheran et al., 2011). Zainudin (2008) reported that flowering species with fragrant floral (Michelia champaca) have dominated the roadside in Kuching, Sarawak. Sreetheran et al. (2011) also mentioned that five main roads in Kuala Lumpur were widely planted with flowering trees such as Peltophorum pterocarpum and Pterocarpus indicus. The 'trending' of flowering tree planting in roadsides has been in vogue since 1778 when they were planted in Malacca and continued to be planted in Penang in 1802 (Ahmad Nazaruddin, 2016; Sreetheran et al., 2011). Ahmad Nazaruddin, Tsan, Normaniza and Adzmi (2014) concluded that flowering trees species are capable of tolerating low soil moisture content, low soil fertility and sites with relatively high soil penetration resistance.

Table 1: Mean analysis for additional attributes influencing roadside tree selection

\begin{tabular}{llll}
\hline Additional Attributes & Mean & Std. Deviation & Rank \\
\hline Trending & 4.70 & 0.50 & 1 \\
Landscape policies & 4.50 & 0.71 & 2 \\
Decision maker & 4.41 & 0.75 & 3 \\
Limiting factor & 4.08 & 1.11 & 4 \\
Framework and plan & 3.94 & 1.39 & 5 \\
Themes & 3.82 & 0.84 & 6 \\
\hline Note : Likert Rating Scale: 1-Strongly disagree, 2-Disagree, 3- Moderate, 4-Agree, 5- Strongly agree
\end{tabular}

\section{The Relationship between Existing and Additional Attributes}

This section elaborated on the relationship between additional and existing attributes influencing the selection of roadside trees (Table 2). Economic factors showed that the maintenance cost against trending displays a very high 
correlation and very strong relationship (tau $=0.917 * *, \mathrm{p}<0.01)$. The trending attribute against economic attributes showed that maintenance cost against landscape policies showed a significant difference $\mathrm{p}<0.01$, high correlation and marked relationship $\left(\operatorname{tau}=0.788^{* *}\right)$. For the cultural constraints, pollution attributes indicated high correlation and marked relationship (tau $=0.820 * *$, $\mathrm{p}<0.01)$. Utilities against limiting factors indicated a very high correlation and very strong relationship (tau $\left.=0.938^{* *}, \mathrm{p}<0.01\right)$ followed by structures and surface cover which showed high correlation and marked relationship between limiting factors $\left(0.082^{* *}, \mathrm{p}<0.01\right)$ and $\left(\operatorname{tau}=0.710^{* *}, \mathrm{p}<0.01\right)$. For the environmental constraints, attributes for physiographic showed a high correlation and marked relationship between limiting factors $(\operatorname{tau}=0.702 * *, \mathrm{p}<0.01)$.

Table 2: Correlation coefficient between existing and additional attributes

\begin{tabular}{|c|c|c|c|c|c|c|}
\hline Attributes & $\begin{array}{l}\text { Framework } \\
\text { and plan }\end{array}$ & Trending & $\begin{array}{l}\text { Landscape } \\
\text { policies }\end{array}$ & $\begin{array}{l}\text { Decision } \\
\text { maker }\end{array}$ & $\begin{array}{l}\text { Limiting } \\
\text { factors }\end{array}$ & Themes \\
\hline \multicolumn{7}{|l|}{$\begin{array}{l}\text { Economic } \\
\text { Factor }\end{array}$} \\
\hline $\begin{array}{l}\text { Maintenance } \\
\text { costs }\end{array}$ & $0.517 * *$ & $0.731 * *$ & $0.559 *$ & 0.587 & 0.397 & $0.233 * *$ \\
\hline $\begin{array}{l}\text { Establishment } \\
\text { costs }\end{array}$ & $0.917 * *$ & $0.036 * *$ & 0.180 & $0.246^{*}$ & 0.541 & $0.249 * *$ \\
\hline Removal costs & $0.788 * *$ & 0.076 & $0.342^{*}$ & 0.158 & $0.206 * *$ & $0.419 *$ \\
\hline \multicolumn{7}{|c|}{ Cultural constraints } \\
\hline Utilities & $0.624 * *$ & $0.310 * *$ & 0.527 & $0.200 * *$ & $0.938 * *$ & $0.678 * *$ \\
\hline Structures & $0.777 * *$ & $-0.040 * *$ & $0.071 * *$ & $0.577 *$ & $0.802 * *$ & $0.206 * *$ \\
\hline Surface covers & $0.299 * *$ & 0.043 & $0.148 * *$ & 0.367 & $0.710 * *$ & $0.251 * *$ \\
\hline Pollution & $0.820 * *$ & $0.215 * *$ & 0.349 & $0.163 *$ & 0.182 & $0.540 * *$ \\
\hline \multicolumn{7}{|c|}{ Environment Constraints } \\
\hline Climatic & $0.362 *$ & $0.589 *$ & $0.413^{*}$ & 0.209 & $0.310 * *$ & $0.377 *$ \\
\hline Edaphic & $0.095^{* *}$ & -0.060 & 0.019 & $0.467 * *$ & $0.267 * *$ & $0.153 * *$ \\
\hline Physiographic & 0.223 & -0.053 & $0.052 * *$ & $0.603^{*}$ & $0.702 * *$ & $0.288 * *$ \\
\hline Biologic & $0.589 * *$ & $0.782 * *$ & $0.513 * *$ & 0.177 & 0.099 & $0.642 * *$ \\
\hline \multicolumn{7}{|l|}{ Social Factors } \\
\hline Aesthetics & $0.785 * *$ & $0.748 * *$ & 0.401 & $0.904 * *$ & 0.317 & $0.894 * *$ \\
\hline $\begin{array}{l}\text { Negative } \\
\text { externalities }\end{array}$ & $0.620 *$ & 0.313 & $0.823 *$ & 0.203 & $0.141 * *$ & $0.676^{*}$ \\
\hline $\begin{array}{l}\text { Functional } \\
\text { utility }\end{array}$ & $0.230 * *$ & $0.874 * *$ & 0.029 & $0.819 * *$ & $0.406 * *$ & $0.290 * *$ \\
\hline $\begin{array}{l}\text { Community } \\
\text { values }\end{array}$ & 0.308 & $0.044 * *$ & $0.745^{* *} *$ & $0.370 *$ & $0.706 * *$ & $0.260 * *$ \\
\hline
\end{tabular}

For the social factors, aesthetics attributes displayed a marked relationship with high correlation against framework and plan (tau $\left.=0.785^{* *}, \mathrm{p}<0.01\right)$. High correlation and weak relationship existed between the aesthetic attributes against 
Ramly Hasan, Noriah Othman \& Faridah Ismail

Developing Malaysian Roadside Tree Species Selection Model in Urban Areas

trending (tau $\left.=0.748^{* *}, \mathrm{p}<0.01\right)$ and high correlation and marked relationship between functional utility against trending ( $\left.\operatorname{tau}=0.874^{* *}, \mathrm{p}<0.01\right)$.

\section{Analysis on Open-Ended Questions}

In the final section of the questionnaire survey, the researchers asked for the opinion of the respondents regarding additional factors for selecting the right tree species. 214 responded that education factors are important in selecting tree species. By having a complete knowledge in trees species, landscape architects should choose the right tree species in the right place. Other than that, the skill, expertise and experience are also needed during the selection of trees species. Someone must have the expertise and skill to ensure the tree species is appropriate and not threatening to the public and properties. Past experiences in selecting trees need to be considered in selecting new tree species.

\section{DEVELOPING MALAYSIAN ROADSIDE TREE SPECIES SELECTION MODEL}

This section discussed the Malaysian Roadside Tree Species Model (Figure 3). The research findings indicate that roadside trees species selection among Malaysian landscape architects is a more complex process than the ones demonstrated in the literature (Roy, 2014; Miller et al. 2015). The researchers found that education factors including knowledge, experience, skill and expertise influence the selection of roadside tree species. Institutional factors including landscape policies, decision makers and framework and plan could influence the way urban roadside trees species are selected, managed and maintained. Limiting factors including space and location also seem to have influenced the Malaysian landscape architects regarding roadside tree species selection practices. Additionally, the researchers found that four new attributes for tree characteristics which are trending, flowering tree, tree form and themes have strong influence in selecting roadside trees, as well as budget constraints including establishment costs, maintenance costs and removal costs. 
PLANNING MALAYSIA

Journal of the Malaysia Institute of Planners (2018)

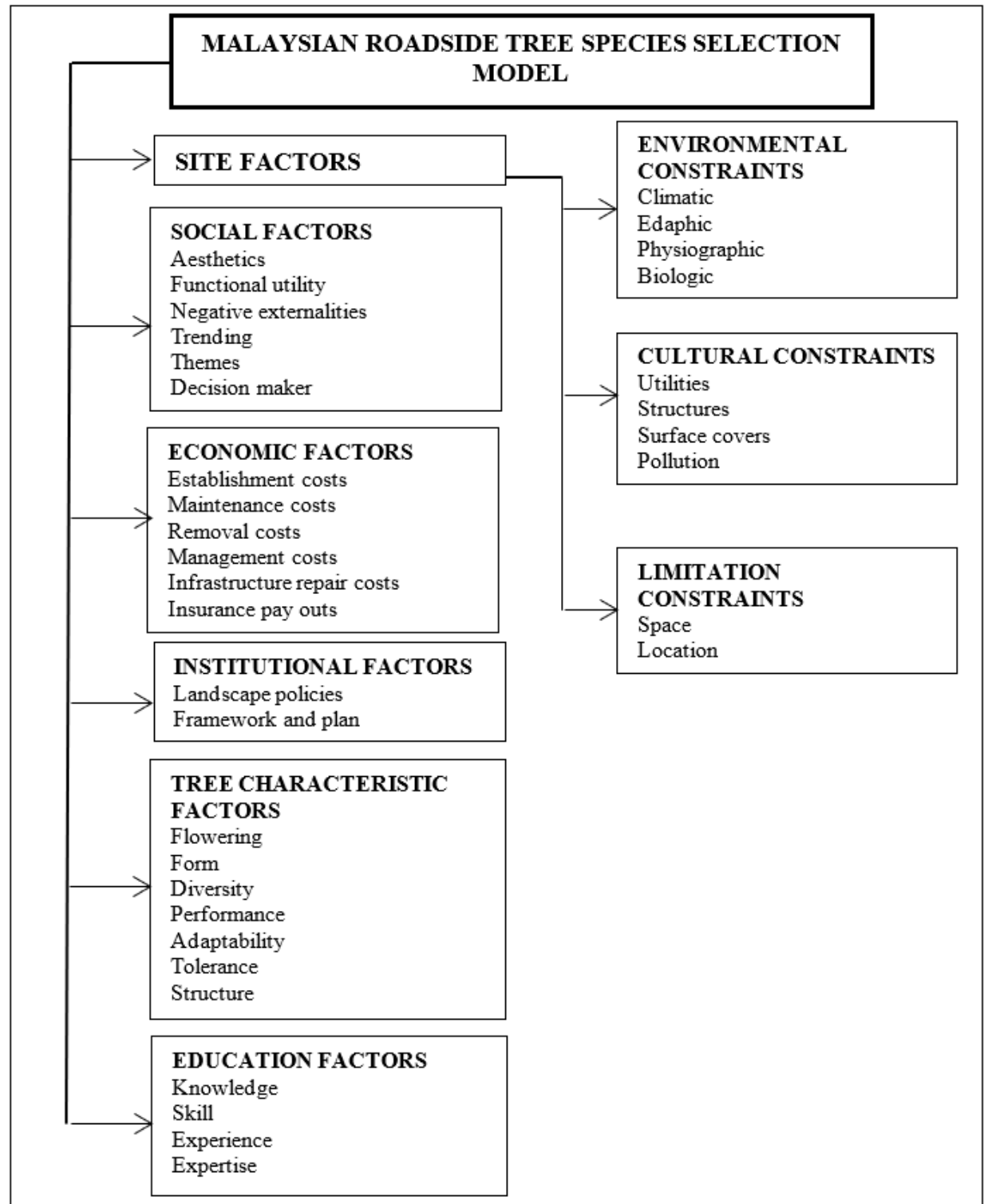

Figure 3: Proposed Malaysian Roadside Tree Species Selection Model

The model (Figure 3) identifies the site factors, social factors, institutional factors, limiting factors, economic factors and tree characteristics factors of roadside tree species selection as reported by Malaysian landscape architects. As part of the tree species selection based on institutional factors mentioned in Roy's (2014) model, the researchers have included landscape 
Ramly Hasan, Noriah Othman \& Faridah Ismail

Developing Malaysian Roadside Tree Species Selection Model in Urban Areas

policies, decision makers, framework and plan of the proposed roadside tree species as reported by Malaysian landscape architects. The researchers added a new factor to the model, namely limiting factors which comprise space and location. These elements influence the selection of tree species as reported by landscape architects, where the limiting space and location features affect tree growth.

\section{CONCLUSION}

In conclusion, six main attributes in selecting roadside trees species were derived from in-depth interviews with 12 landscape architects who were authorised in giving approval for the Landscape Planting Plan and proposing the tree species at the local authority stage. The attributes include framework and plan, trending, landscape policies, decision makers, limitations constraints and themes. All the attributes reported by the interviewer were based on the current practices during the selection of trees species. The findings reported that the majority of additional attributes indicated a positive correlation and have a relationship with existing attributes from the Tree Species Selection Model by Roy (2014). Therefore, all of the additional attributes are appropriate to fit into the Malaysian Roadside Tree Species Model.

\section{ACKNOWLEDGEMENT}

This research was funded by the Geran Insentif Penyeliaan (GIP) (600-IRMI / MyRA 5/3/GIP (025/2017) from the Research Management Centre, Universiti Teknologi MARA, Shah Alam, Selangor, Malaysia

\section{REFERENCES}

Ahmad Nazarudin, M. R. (2016). Xanthostemon Chrysanthus (F. Muell.) Benth.: A new flowering tree for urban landscapes. International Journal of Agriculture, Forestry and Plantation, 3, 50-54.

Ahmad Nazarudin, M. R., Tsan, F. Y., Normaniza, O. \& Adzmi, Y. (2014). Growth performance and flowering occurrence of Xanthostemon chrysanthus in two selected urban sites in Kuala Lumpur, Malaysia. Journal of Tropical Forest Science, 26(3), 428-434.

Battipaglia, G., Marzaioli, F., Lubritto, C., Altieri, S., Strumia, S., Cherubini, P., \& Cotrufo, M. F. (2010). Traffic pollution affects tree-ring width and isotopic composition of Pinus pinea. Science of the total Environment, 408(3), 586-593.

Hasan, R., Othman, N., \& Ismail, F. (2016). Roadside Tree Management in Selected Local Authorities for Public Safety. Procedia-Social and Behavioral Sciences, $234,218-227$

IResponz system, (2017). Retrieved from http://www.mpsj.gov.my/iresponz/sso/ index.cfm?option=help 
Key, T., Warner, T. A., McGraw, J. B., \& Fajvan, M. A. (2001). A comparison of multispectral and multitemporal information in high spatial resolution imagery for classification of individual tree species in a temperate hardwood forest. Remote Sensing of Environment, 75(1), 100-112.Kondo, M. C., Han, S., Donovan, G. H., \& MacDonald, J. M. (2017). The association between urban trees and crime: Evidence from the spread of the emerald ash borer in Cincinnati. Landscape and Urban Planning, 157, 193-199.

Krzyżaniak, M., Świerk, D., Walerzak, M., \& Urbański, P. (2015). The impact of urban conditions on different tree species in public green areas in the city of Poznan. Folia Horticulturae, 27(2), 89-97.

Miller, R. W., Hauer, R. J., \& Werner, L. P. (2015). Urban forestry: Planning and managing urban greenspaces. Long Grove, IL: Waveland Press.

Moore, G. M. (2009). People, trees, landscapes and climate change. In H. Sykes (Ed.), Climate change on for young and old (pp. 132-149). (n.p.): Future Leaders.

Mullaney, J., Lucke, T., \& Trueman, S. J. (2015). A review of benefits and challenges in growing street trees in paved urban environments. Landscape and Urban Planning, 134, 157-166.

Nor Azah, A. A. (2015). Ringkasan keperluan latihan pelanggan. institut latihan kesejahteraan bandar, perumahan dan kerajaan tempatan (IKPKT).

Pauleit, S., Jones, N., Garcia-Martin, G., Garcia-Valdecantos, J. L., Rivière, L. M., VidalBeaudet, L., \& Randrup, T. B. (2002). Tree establishment practice in towns and cities: Results from a European survey. Urban Forestry \& Urban Greening, $1(2), 83-96$.

Roy, S. (2014). Factor influencing Australian local governments' street tree species selection (Doctorate dissertation). Griffith University, Brisbane, Australia.

Salmond, J. A., Tadaki, M., Vardoulakis, S., Arbuthnott, K., Coutts, A., Demuzere, M., \& McInnes, R. N. (2016). Health and climate related ecosystem services provided by street trees in the urban environment. Environmental Health, 15(1), S36.

Schroeder, H., Flannigan, J., \& Coles, R. (2006). Residents' attitudes toward street trees in the UK and US communities. Arboriculture and Urban Forestry, 32(5), 236.

Sieghardt, M., Mursch-Radlgruber, E., Paoletti, E., Couenberg, E., Dimitrakopoulus, A., Rego,F., \& Randrup, T. B. (2005). The abiotic urban environment: Impact of urban growing conditions on urban vegetation. In C. Konijnendijk, K. Nilsson, T. Randrup, \& J. Schipperijn (Eds), Urban forests and trees (pp. 281-323). New York: Springer.

Sistem Talian Aduan Rakyat (2017). Retrieved from http://stars.selangor.gov.my $/ \operatorname{login} . h t m l$

Sreetheran, M., Adnan, M., \& Khairil Azuar, A. K. (2011). Street tree inventory and tree risk assessment of selected major roads in Kuala Lumpur, Malaysia. Arboriculture and Urban Forestry, 37(5), 226.

Wiseman, P. E. (2017). Roadside tree risk management by state departments of transportation in the Mid-Atlantic region: A pilot study conducted by the virginia tech department of forest resources and environmental conservation. (n.p.): (n.p.). 
Ramly Hasan, Noriah Othman \& Faridah Ismail

Developing Malaysian Roadside Tree Species Selection Model in Urban Areas

Vogt, J., Gillner, S., Hofmann, M., Tharang, A., Dettmann, S., Gerstenberg, T., \& Roloff, A. (2017). Citree: A database supporting tree selection for urban areas in temperate climate. Landscape and Urban Planning, 157, 14-25.

Yaman, A. R., Jamil, M. Z., \& Yaakob, R. (2011). Manual pengurusan risiko pokok ameniti. Kuala Lumpur: Jabatan Landskap Negara.

Yan, P., \& Yang, J. (2018). Performances of urban tree species under disturbances in 120 cities in China. Forests, 9(2), 50.

Zainudin, S. R. (2008). Diversity of urban trees at protocol and residential roads in Kuching City North, Sarawak and their management issues (pp. 71-80). 